\title{
Paediatric ventriculoperitoneal shunt infection caused by Actinomyces neuii
}

\author{
Ian A Anderson, ${ }^{1}$ Fazain Jarral, ${ }_{1}^{1}$ Kavita Sethi, ${ }^{2}$ Paul D Chumas ${ }^{1}$
}

${ }^{1}$ Department of Neurosurgery, Leeds General Infirmary, Leeds, West Yorkshire, UK

${ }^{2}$ Department of Microbiology, Leeds General Infirmary, Leeds, West Yorkshire, UK

\section{Correspondence to}

lan Anderson,

ian.anderson@leedsth.nhs.uk

Accepted 3 May 2014

\section{SUMMARY}

We present the first reported case of ventriculoperitoneal shunt infection secondary to Actinomyces neuii in a paediatric patient. Our patient was managed with temporary shunt removal, intrathecal antibiotics and a prolonged course of intravenous and then oral antibiotics. She went on to make a complete recovery. Subsequent cerebrospinal fluid analysis at 5 months post-treatment demonstrated no evidence of residual infection.

\section{BACKGROUND}

Only one previous (adult) case has been reported with this rare organism. In addition to being the first reported paediatric case, this case differs from the adult case in so far as there was neither history of dental procedures nor evidence of oral infection; the child was otherwise well.

\section{CASE PRESENTATION}

A 6-month-old girl was brought to her local hospital with a 5-day history of fevers and a 24-h history of diarrhoea and abdominal bloating. She was born with a spina bifida (open lumbosacral myelomeningocoele), surgically closed at day 2 of life and a ventriculoperitoneal (VP) shunt inserted at day 13 of life for consequent hydrocephalus. There was no suggestion of specific neurological symptoms (eg, drowsiness, vomits, seizures and sun-setting).

On examination, the child had fever $\left(38.8^{\circ} \mathrm{C}\right)$ but otherwise baseline observations were normal. Body weight was $8.1 \mathrm{~kg}$. Neurological examination revealed no new deficit. All prior surgical wounds were well healed. Abdominal examination revealed a distended but soft abdomen which appeared tender to palpation.

\section{INVESTIGATIONS}

Blood tests showed an elevated white cell count (WCC) of $33.0 \times 10^{9} / \mathrm{L}$ and $\mathrm{C}$ reactive protein (CRP) was similarly elevated at $353 \mathrm{mg} / \mathrm{L}$. Urine tested positive for leucocytes but subsequent cultures were negative. No pathogens were detected on faecal culture and virology.

The child was transferred to the neurosurgical centre for observation. An ultrasound of the abdomen was performed and this demonstrated a small $(5.4 \times 1.5 \times 5.4 \mathrm{~cm})$ thick-walled fluid collection in the right side of the abdomen which was likely to represent a small infected fluid collection secondary to an infected VP shunt.
In view of the ultrasound findings, the shunt valve reservoir was sampled percutaneously to rule out shunt colonisation. Initial cerebrospinal fluid (CSF) microscopy showed a WCC of $20 \times 10^{6} / \mathrm{L}$ (70\% polymorphs, 30\% lymphocytes) and a red cell count of $54 \times 10^{6} / \mathrm{L}$. Gram-positive cocci were noted to be present in the sample.

\section{TREATMENT}

The patient was taken to theatre and the entire shunt system was removed and an external ventricular drain (EVD) inserted for intrathecal delivery of antibiotics. The patient was empirically started on intrathecal vancomycin $(10 \mathrm{mg}$ once daily) and intravenous cefotaxime $(50 \mathrm{mg} / \mathrm{kg}$ four times per day) and metronidazole $(7.5 \mathrm{mg} / \mathrm{kg}$ three times per day), pending further culture and sensitivity results. The patient was systemically well within $24 \mathrm{~h}$ of shunt removal.

The paediatric surgical team reviewed the patient and felt that the abdominal fluid collection would not need draining. Repeat abdominal ultrasound scans at 4 and 9 days postshunt removal showed that the collection had reduced in size and completely resolved, respectively.

Non-haemolytic colonies were seen on the blood agar plate after $36 \mathrm{~h}$ which stained as Gram-positive bacilli; they tested catalase negative. They were subsequently identified as Actinomyces neuii by $16 \mathrm{~s}$ PCR. The isolate tested sensitive to penicillin, vancomycin and cefotaxime but resistant to ciprofloxacin. At this point, the CSF WCC was $<1 \times 10^{6} / \mathrm{L}$ and multiple CSF cultures had showed no growth. Blood CRP was $<5.0 \mathrm{mg} / \mathrm{L}$ and WCC was $13.68 \times 10^{9} / \mathrm{L}$. After discussion with the microbiology team, it was decided that 11 days of intrathecal antibiotics would be sufficient for shunt reinsertion to be considered safe. The patient was changed to intravenous benzyl-penicillin $(50 \mathrm{mg} / \mathrm{kg}$ four times per day); cefotaxime and metronidazole were discontinued. A new VP shunt was inserted.

The patient completed a 4-week course of intravenous benzyl-penicillin following insertion of the new VP shunt and was then converted to high-dose oral amoxicillin for a further 3 months. When reviewed at the end of the antibiotic course, the child had remained well and blood parameters were normal; CRP $<5.0 \mathrm{mg} / \mathrm{L}$, WCC $6.38 \times 10^{9} / \mathrm{L}$.

\section{OUTCOME AND FOLLOW-UP}

Unfortunately, the child re-presented with acute hydrocephalus, about 5 months following the reinsertion of her VP shunt. In theatre, the proximal catheter was found to be completely occluded 
and was replaced. Interestingly, CSF microscopy from the sample taken in theatre proved that the infection had been successfully eradicated: WCC $<1 \times 10^{6} / \mathrm{L}$, no organisms on Gram stain and no growth on cultures. The child went on to make a full recovery following surgery and at 4 months postoperative remains completely asymptomatic.

\section{DISCUSSION}

The incidence of paediatric VP shunt infections quoted within the literature varies between $5 \%$ and $10 \% .^{12}$ One of the several independent risk factors for shunt infection is age at time of shunt placement (increasing risk at younger age). ${ }^{3}$ The clinical manifestations of an infected VP shunt system vary. In one recent review of the literature, the mean number of paediatric patients with VP shunt infections whose temperature was $>38.5^{\circ} \mathrm{C}$ was $77 \% .^{3}$ At least half of the patients will have no overt signs of hydrocephalus, such as headaches, seizures or drowsiness. ${ }^{4-6}$ Abdominal pain has been noted to be a presenting feature in between $0 \%$ and $36 \%$ of patients in recent series. $^{45}$

The most common causative organisms of VP shunt infection are Gram-positive cocci, although in one series of 54 patients with infected VP shunts, CSF cultures yielded a positive result in only $9 \%$ of cases. ${ }^{7}$ Pathogens that have colonised the patient's skin are the most common source of infection; specifically coagulase-negative staphylococci and Staphylococcus aureus account for a cumulative total of $47-89 \%$ of infections. ${ }^{6} 8$ Gram-negative infections are rarer, accounting for $7-24 \%$ of infections. ${ }^{9}$ Anaerobic bacteria and fungal pathogens (Candida spp.) are also recognised causes of shunt infection, although the incidence of these is relatively low.

Actinomyces are Gram-positive anaerobic bacteria that form a part of the oral flora. Actinomyces spp. account for a minority of cases of anaerobic meningitis in children. ${ }^{10}{ }^{11}$ One review of 70 cases of central nervous system Actinomyces infection implicated the organism in brain abscess (67\% of cases), meningitis (13\%), actinomycoma (7\%), subdural empyema (6\%) and epidural abscess $(6 \%)$ but there were no cases of VP shunt infection associated with the organism. ${ }^{12}$

A. neuii was first described in 1994 and is unusual on account of its aerobic growth, lack of branching and sites of infection. ${ }^{13}$ It has been typically reported from skin and soft tissue abscesses and infected atheroma. The only previously reported case of VP shunt infection caused by $A$. neuii is that of a 64-year-old woman who presented with low-grade fever, vomiting and ataxia. ${ }^{14}$ CSF from the patient cultured $A$. neuii subsp. neuii. The infection was thought to be secondary to dental cleaning and teeth scraping, performed under amoxicillin prophylaxis some 3 months earlier. The patient was treated with shunt removal and insertion of EVD. A new shunt was inserted at 15 days. The patient completed a 6-week course of intravenous penicillin, followed by 6 months of oral penicillin as an outpatient and did well thereafter. No intrathecal antibiotics were prescribed.

To the best of our knowledge, this is the first case of $A$. neuii causing VP shunt infection in a paediatric setting. Interestingly, our patient was noted not to have any teeth yet and there was no evidence of oral infection. We elected to treat our patient aggressively with high-dose intravenous and intrathecal antibiotics followed by a prolonged oral regimen thereafter. However, given initial intrathecal antibiotics, we decided to give a shorter 3-month oral amoxicillin. The child has made a good recovery with no new neurological deficit.

The fact that the shunt subsequently failed again (albeit due to proximal catheter obstruction rather than infection) means that we have the unusual scenario of confirmatory CSF samples from 5 months after the intrathecal antibiotics had ceased and 2 months after oral therapy had been completed which confirm that the infection had been eradicated. Unfortunately the proximal catheter that was removed at the time of the most recent shunt revision was discarded. At 4 months following the most recent revision of the shunt, the child remains completely well.

\section{Learning points}

Actinomyces is a rare but possible cause of shunt infection that can occur in adults as well as children.

- While Actinomyces infections of the central nervous system are thought to be due to oral causes, this may not always be the case.

- Patients should be treated aggressively (from an antibiotic perspective). In our case, initial intrathecal antibiotics helped to reduce the duration of parenteral and subsequent oral antibiotics with a good outcome; we would advocate any future cases be managed in a similar fashion.

Contributors Data collection and preparation of the initial manuscript was by IA Literature review was undertaken by IA and FJ. The manuscript was reviewed and amended by $\mathrm{KS}$ and $\mathrm{PC}$. PC is the senior author.

\section{Competing interests None.}

Patient consent Obtained.

Provenance and peer review Not commissioned; externally peer reviewed.

\section{REFERENCES}

1 Rowin ME, Patel VV, Christenson JC. Pediatric intensive care unit nosocomial infections: epidemiology, sources and solutions. Crit Care Clin 2003;19:473-87.

2 Choux M, Genitori L, Lang D, et al. Shunt implantation: reducing the incidence of shunt infection. J Neurosurg 1992;77:875-80.

3 Prusseit J, Simon M, von der Brelie C, et al. Epidermiology, prevention and management of ventriculoperitoneal shunt infections in children. Pediatr Neurosurg 2009;45:325-36.

4 Turgut $M$, Alabaz D, Erbey $F$, et al. Cerebrospinal fluid shunt infections in children. Pediatr Neurosurg 2005;41:131-6.

5 Kontny U, Höfling B, Gutjahr $\mathrm{P}$, et al. CSF shunt infections in children. Infection 1993;21:88-9.

6 Ronan A, Hogg GG, Klug GL. Cerebrospinal fluid shunt infections in children. Pediatr Infect Dis J 1995;14:782-6.

7 Vanaclocha V, Sáiz-Sapena N, Leiva J. Shunt malfunction in relation to shunt infection. Acta Neurochir (Wien) 1996;138:829-34

8 Enger PØ, Svendsen F, Sommerfelt K, et al. Shunt revisions in children-can they be avoided? Experiences from a population-based study. Pediatr Neurosurg 2005; $41: 300-4$

9 Stamos JK, Kaufman BA, Yogev R. Ventriculoperitoneal shunt infections with gram-negative bacteria. Neurosurgery 1993;33:858-62.

10 Brook I. Meningitis and shunt infection caused by anaerobic bacteria in children. Pediatr Neurol 2002;26:99-105.

11 Brook I. Anaerobic infections in children. Microbes Infect 2002;12:1271-80.

12 Smego RA Jr. Actinomycosis of the central nervous system. Rev Infect Dis 1987;9:855-65.

13 Funke G, Stubbs S, von Graevenitz A, et al. Assignment of human-derived CDC Group 1 Coryneform Bacteria and CDC Group 1-like Coryneform Bacteria to the genus Actinomyces as Actinomyces neuii subsp. anitratus subsp.nov. Int I Syst Bacteriol 1994;44:167-71.

14 Watkins RR, Anthony K, Schroder $S$, et al. Ventriculoperitoneal shunt infection caused by Actinomyces neuii subsp. neuii. J Clin Microbiol 2008;46:1888-9. 
Copyright 2014 BMJ Publishing Group. All rights reserved. For permission to reuse any of this content visit http://group.bmj.com/group/rights-licensing/permissions.

BMJ Case Report Fellows may re-use this article for personal use and teaching without any further permission.

Become a Fellow of BMJ Case Reports today and you can:

- Submit as many cases as you like

- Enjoy fast sympathetic peer review and rapid publication of accepted articles

- Access all the published articles

- Re-use any of the published material for personal use and teaching without further permission

For information on Institutional Fellowships contact consortiasales@bmjgroup.com

Visit casereports.bmj.com for more articles like this and to become a Fellow 